\title{
Social Service Policy in Handling Beggars in Lhokseumawe City
}

\author{
Cut Sukmawati*1, Bambang Heru Prasatyo ${ }^{1}$ \\ ${ }^{1}$ Faculty Science Social and Science Politics, Universitas Malikussaleh, Aceh Utara, Indonesia \\ Corresponding Author: cutsukmawati@unimal.ac.id
}

\begin{abstract}
Lhokseumawe City, in implementing PP No. 31 of 1980 on Tackling Homeless and Beggars and Qanun Aceh No. 11 of 2013 on Social Welfare authorizes Social Services in taking policies in handling beggars and homeless people. A total of 32 people in 2019 and 25 people in 2018 have been caught in raids by Social Services. This research used qualitative research method with descriptive type analysis. Data collection techniques were observation, interviews and documentation. The data obtained by the researchers were analyzed with several steps, namely data collection, data reduction, data presentation, and finally, the withdrawal of conclusions. The results showed that the social service policy in handling beggars in Lhokseumawe city has not been maximized; there are three stages in handling beggars, namely preventive, regressive and rehabilitative stages. Preventive Stage of Social Services provides assistance through programs that have been created to reduce the poor to beggars, the second stage of Refresive social services in collaboration with cross-sectoral such as Satpol Pamong Praja (PP) and Wilayatul Hisbah (WH) conduct raids on beggars and at the Rehabilitative stage social services have not been able to do so, only giving direction and guidance not to beg anymore. But all measures have not been able to reduce the number of beggars. Barriers in the handling of beggars are divided into two, namely internal and external. Internal, it is the absence of a legal umbrella for social services in sanctioning beggars, while externally; it is from the beggars themselves who do not want to listen to the direction and guidance of social services not to beg anymore.
\end{abstract}

Key words: policy; social services; handling; beggars;

\section{Introduction}

Social welfare problems are inevitable in people's lives, especially those in urban areas, namely the problem of street children, homeless people, penegemis and buskers. This social problem is an accumulation of various problems that occur. Starting from poverty, low level of education, lack of work skills owned environment, socio-cultural, health and so on. According to Government Regulation or PP No. 31 of 1980 concerning The Management of Homeless And Beggars is said bahwa, Homeless people are people who live in a state of not in accordance with the norms of a decent life in the local community, and do not have a permanent place of residence and work inacertain area and livewandering in public places. Meanwhile, the Beggars are the ones who earnmoney by asking in public in a variety of ways and reasons to expect mercy from others.

In PP No. 31 of 1980 explained the stages of handling beggars, namely, First, preventive efforts are organized efforts that include counseling, guidance, training, and education. Second, repressive efforts to eliminate embezzlement and beggarship, as well as prevent the spread of society through authorized institutions. Third, rehabilitative efforts are efforts to provide care, recovery and training to homeless people and beggars.

\section{Methods}

The author conducted the research in Lhokseumawe City and its locus at Lhokseumawe city social service. The author chosed the location of the research in Social Services because in this study actors from the implementing policy are social services and information can be obtained at the Service and with the support of the observations of researchers in the field. The author also choosed locations where beggars do begging activities every day such as in supermarkets, Islamic 
Centre Mosque, Riyadh Park, Hiraq Square and at red lights and restaurants.

This research used a descriptive qualitative method. Qualitative research is a researcher who has a higher level of criticalism in all research processes. The authors of this study used infoman retrieval techniques with purposive techniques where samples were selected taking into account things related to this study. Informant himself is a person who knows the situation and condition of the problem in the research, so that the information obtained in accordance with the purpose of the research. While the informants of the beggar, authors used random sampling techniques. The informants were determined but anyone whom found in the field to provide information about this study.

Informant research from academics the authors choosed in accordance with the study of social sciences, where more specifically the study of sociological science and anthropology, of course the informant is more aware of how the view of this beggar through social sciences. For informants of beggar, authors just toke it randomly and most beggars did not want to be interviewed either overtly or secretly. They always shyed away when there were others who want to talk to them. The informants below were interviewed for information and had been written in chapter IV of the results and discussion of this study.

Table 1. List of Names of Research Informants

\begin{tabular}{cll}
\hline No. & \multicolumn{1}{c}{ Name } & \multicolumn{1}{c}{ AS } \\
\hline 1. & Mrs. Susi Harmiza, SH & as Head of Rehabilitation and Protection of Social Security \\
\hline 2. & Mrs. R.R Yustirostina, SE & $\begin{array}{l}\text { as Section Head of social rehabilitation, disability and social } \\
\text { tuna }\end{array}$ \\
\hline 3. & 10/20 2015 - 10:00 & Academician (Lecturer in Unimal Sociology) \\
\hline 4. & $\begin{array}{l}\text { Mr. Teuku Kemal Pasya, S.Ag., } \\
\text { M.Hum }\end{array}$ & Academician (Lecturer in Unimal Anthropology) \\
\hline 5. & Darmianti's grandmother & Beggar \\
\hline 6. & Mr. Lamuli & Beggar \\
\hline 7. & Muhammad Akhyar & Beggar \\
\hline
\end{tabular}

In taking the author's data source here divides into two types of sources, among others: Primary data source, primary data source, this data source comes from interviews conducted by the author in the time of writing this study. Secondary data source, the data obtained is derived from documentation that existed during the research as well as books or journals that are used as a reference in the writing of this research that can support this research information.

Data collection techniques through guided interviews (guided interviews) researchers only ask things thatg have been prepared before. Observation according to Bunging (2007:115-117), unstructured observations are observations made without guidelines so that researchers develop their observations according to what happened in the field. Third is documentation. Data analysis techniques start from data collection, data reduction, data presentation and lastly are drawing conclusion.

\section{Results and Discussions}

\section{Overview}

Rahmad Syahputra Rangkuti, S.Sos. M.Sos as Head of Sociology Study Program of Malikussaleh University, responded to beggars:

"Sociologically Urban, Homeless and Beggars Arise from the aspect of not absorbing all the people who do urban to the city so that there are two jobs that appear, the Formal Sector of those who can afford to enter it with a fixed salary and another Informal Sector, 
well one that goes there is what is meant by Bums and Beggars, and it becomes one of the urban problems" (Interview February 25, 2020).

Teuku Kemal Pasya, S.Ag. M.Hum as Lecturer in Anthropology, said:

"In general, beggars are the impact of poverty that occurs or welfare that is not achieved, beggars are not only a problem of poverty but a cultural problem as well,"

(Interview February 26, 2020).

The phenomenon of beggars in Lhokseumawe city has become common place for the people of Lhokseumawe city. Begging is not an unlawful act but if you look at the development of beggars so massively of course the question arises why more and more beggars. But behind it all,the phenomenon of the rise of beggars in the city becomes an interesting thing to research,and the author explains some discussions about beggars below.

\section{Origin of Beggars}

In the handlerand beggar is one of the duties and authorities of the Social Service. Handling beggars is not something that can be considered easy to solve, it takes cooperation not only between Social Services and Satpol PP but also requires cooperation with the City Government, Non-governmental organization, and the community to solve this problem, for that researchers have conducted interviews with several informants.

Based on the researcher's interview with R.R. Yustirostina's mother, SE as the Head of social rehabilitation, disability and social tuna section, said that:

"Beggars in Lhokseumawe are mostly or more dominant it's their origin is not the population of Lhokseumawe City, we ourselves as Social Services know it when conducting raids, and when recorded it turns out, they are mostly from outside Lhokseumawe city" (Interview December 2019).

From the results of the interview above researchers concluded that of all the beggars who were caught raids and recorded most and the majority are migrants from outside Lhokseumawe city. Only a small part of it comes from Lhokseumawe City itself.strengthened by the results of the researcher's interview withone of the beggars, namely Mr.Lamuli whosaid:

"Thefather himself is not a Lhokseumawe man, the father's village of pumpkin panton, the father from there here riding a motorcycle alone, the father's son is still small and still in school, so the father went alone" (Interview February 20, 2020).

The next informant was a grandmother named Darmianti,who was a beggar who used to be in front of the Office of BRI Lhokseumawe said:

"Grandma now lives in Nisam, so if you come here with grandma's granddaughter, and her return is also picked up again with grandchildren" (Interview February 19, 2020).

Based on the results of the interview with the researchers with the two beggars above can be drawn the conclusion that they are not from Lhokseumawe city.

\section{Responses About Beggars}

Beggars are the ones who make money by begging in public, both at intersections and in shopping malls by expecting the mercy of people with their own mode. Researchers conducted an interview with one of the lecturers malikussaleh University, mr.RahmadSyahputraRangkuti, S.Sos., M.Sos as the Head of Sociology Study Program, responding to beggars:

"Sociologically Urban, Homeless and Beggars Arise from the aspect of not absorbing all the people who do urban to the city so that there are two jobs that appear, the Formal Sector of those who can afford to enter it with a fixed salary and another Informal Sector, well one that goes there is what is meant by Bums and Beggars. And it becomes one of the urban problems" (Interview February 25, 2020). 
Based on the results of the interview above, researchers concluded sociologically urban emergence of beggars as a result of the lack of jobs available in urban areas so that people who do urban become unemployed and can not produce anything. In sociology it is known as the Informal sector,and it becomes a problem that exists in every urban especially big city.

\section{Beggar's Motives}

In doing his activities beggars have their own motives or ways. They use different motives so that people feel compassion and pity so that they get alms. In some cases there are beggars who are pushy, they will not leave if not given money. During the study, researchers divided into two groups namely first, organized beggars and secondly, disorganized beggars.

\section{a. Organized beggars}

Organized beggars are usually done by children, and they have a target income in one begging. As muhammadAkhyar said as one of the organized beggars:

"this is just out (after maghrib) new this road, can be just alittle, I have to carik 70 thousand new I come home is still 5 thousand carik 65 thousand more, if not yacan not go home, my house in tumpokteungoh stay with grandma, if I go home naekbecakkalo can 70 thousand if not yes on foot, return at 12 pm"(interview September 18, 2020).

\section{b. Disorganized Beggars}

This type of beggar is a beggar who is usually found on red carpets and in cafes or restaurants. Usually they do their own activities unstructured just alone or alone.

As said by R.R. Yustirostina, SE as the Head of Social Rehabilitation Section, disability and social tuna, said that:

"We see that falsifying feet with like a foot of butts, indeed here has not been found but we have heard it is here, then many children who ask for money at home eat, they actually if given money they use to belik glue to be sucked or sometimes play internet café, so we if anyone asks for us, we do not love money but love food or drink with them better so" (Interview November 27, 2019)

From the mother's statement we know that beggars also have a motive to do their activities, and children also sometimes ask for money to restaurant visitors and after that the money is used improperly.

\section{Handling Beggars by Social Services}

In handling beggars in Lhokseumawe city the government itself through Social Services has made efforts in dealing with the rise of beggars. Handling beggars themselves is divided into 3 stages inaccordance with PP No. 31 of 1980 on Handling Homeless and Beggars, namely Preventive, Regressive and Rehabilitative. Related to this stage the author has explained below that obtained during the study.

\section{Preventive}

At this stage social services have made a sign urging to make donations and donations in the orphanages or at established institutions, this board is installed in Riyadh Park and the front red light suzuya. 


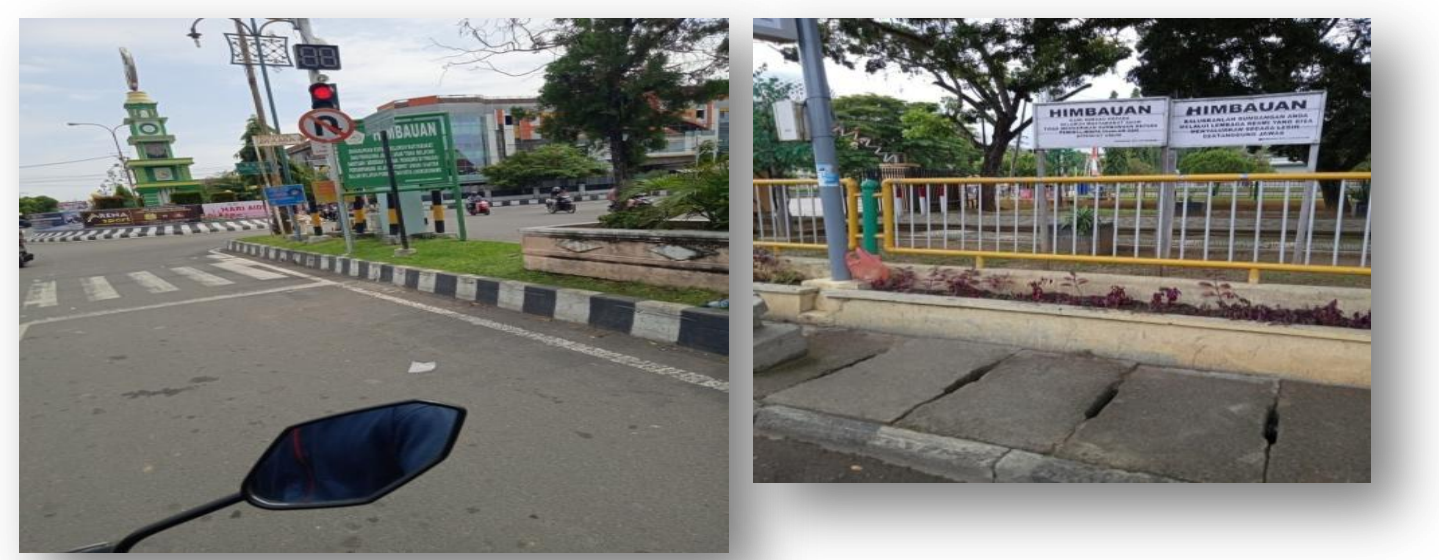

\section{Refresif}

Susi Hermiza, SH as Head of Rehabilitation and Protection of Social Security, stated:

"Social Services have conducted raids homeless and beggars (Gepeng) in collaboration with cross-sectoral related in this case Satpol Pamong Praja (PP) and Wilayatul Hisbah $(\mathrm{WH})$. The raid was conducted in the afternoon and evening on July 29, 2019. The gepeng raid was conducted in points considered vulnerable, such as Riyadh Park, Hiraq Park, Cunda Gas Station, Kuta Blang Gas Station, and Asiamart and other Supermarkets in Lhokseumawe City. After the raid, Gepeng who was caught/raided was taken and placed in the Office of Satpol PP and WH, then given guidance and direction by the Head of Social Service Lhokseumawe city. Previously they were recorded and signed an affidavit that essentially will not beg again in public, but I see the deterrent effect does not exist" (Interview February $25,2020)$.

Based on the statement from the Head of Rehabilitation and Protection of Social Security, the researcher concluded that Social Services had taken action in the form of raids and were taken to the Office of Satpol PP and then briefed beggars not to beg again by the Head of Social Services. Then they are recorded name, origin or place of residence then the reason they beg and they are asked to sign a statement not to beg again, after that then they are fed their new home if the residents of Lhokseumawe and if they come from outside the city they will be given a fee to go home, but so far the deterrent effect does not exist. Social Services can not arrest them because if they have been arrested do not know where to be placed because of the absence of a shelter.

\section{Rehabilitative}

Mrs. Susi Hermiza, SH as Head of Rehabilitation and Protection of Social Security, said:

"Social Services give a briefing not to beg again then we make a statement so as not to repeat it again, but I see the deterrent effect is not there, do not know why, if we catch us do not know where they are placed because we do not have a shelter, and because of the lack of funding also so given coaching alone for a while" (Interview February 25, 2020).

Based on the results of the interview above it was concluded that Social Services do not have shelters or shelters for homeless people and beggars. A shelter is needed to accommodate the homeless and beggars and provide coaching to them in the form of skill training in order to restore their social functions.

\section{Barriers to Handling Beggars by Social Services}

\section{Internal Barriers}

The government through Social Services delegates the task and authority to solve the problem of social welfare, one of which is the handling of beggars. In handling beggars Social services have obstacles that cause less maximum action from the Social Service. These obstacles arise due to the 
lack of improvement of this Social Service task. Judging from the internal obstacles that can be said so far is the first; the problem of Resources is the lack of budget in the implementation of beggar handlers.

\section{External barriers}

Handling beggars is not an easy thing to overcome because it is not only internal problems that must be faced by Social Services. In addition to internal problems such as budgets and the legal umbrella of Social Services also get obstacles from external, these external barriers come from beggars themselves and the lack of synergy between government, private and NGOs. These obstacles will contribute to the unested handling of these beggars.

\section{Discussion}

Beggars are people who begin public expecting mercy from others. The phenomenon of beggars is a phenomenon that actually needs special attention by the government in this field, namely social services. Lhokseumawe itself which is one of the cities that use Islamic sharia as its rule becomes an easy target to make it much used as an object of begging place. The phenomenon of beggars is very interesting to research, what causes the rise of beggars and how the government responds to this problem.

Some cases in Lhokseumawe show that beggars make begging a profession and they love to do it. This is evidenced by the existence of a viral beggar who turns out he was carrying a vios sedan car and when caught on camera he does not feel embarrassed or sorry, there are also beggars who are pushy to give money then many children are also found asking for money to visitors to the restaurant or park while the child is not have reason to have to beg with good physical condition.

Social Services has been conducting beggar feeding activities starting from the first, preventive stage where the Social Service put up a sign telling people not to make donations to beggars but to established institutions or foundations and this is just a suggestion does not mean we should not give alms on the street to beggars. Second, refresive is the implementation of raids and the control of beggars. This stage has been carried out by socialservices along across sectors such asSatpol PP and Wilayatul Hisbah as well as with the Sector Police. Third, the Rehabilitative stage of this stage is actually the most important to restore the social function of beggars by creating programs to give them skills to be able to work and not repeat their actions.

But on the other hand they are not always guilty, because they are just trying to make a living to meet their daily needs. So by force they remain recklessly begging during this pandemic, and this should be of particular concern for Social Services to take appropriate and eisien policies.

\section{Conclusions}

Lhokseumawe City, Social Service as an agency responsible for social welfare, has been trying to handle beggars through preventive and regressive stages such as installing appeal boards at a number of points in Lhokseumawe City and conducting Razia Gepeng. But that is not enough to deal with the beggar problem, because the most important stage is at the rehabilitative stage, where this stage can empower beggars to be like ordinary people again. Researchers divide there are several types of beggars in Lhokseumawe city that can be found as follows:

a. Structured Beggars
b. Unstructured Beggars

\section{Suggestion}

The need for special attention of Social Services in handling beggars in Lhokseuawe city by issuing the right policies so that the phenomenon of beggars can be reduced. 


\section{References}

Anggara, Sahya. (2014). Public policy, Bandung: Pustaka Setia

Arifuddin, Alfan, (2017), Psychology Beggars, Malang: Ocean Mountain

Dude, M.Burhan, (2007), Qualitative Research, Fourth Printing, Jakarta: KencanaPrenada Media Group.

Dunn, William N, (2003), Introduction to Public Policy Analysis, SecondEdition, Yogyakarta: Gadjah Mada University Press

Fermana, Surya, (2009), Public Policy, Yogyakarta: Ar-Ruzz Media.

Thoha, Miftah (2008), Contemporary Public Administration Science, First Edition, Jakarta: KencanaPrenadamedia Group

Parsons, Wayne, (2006), Public Policy: Introduction to Policy Analysis Theory and Practice, Second Printing, Jakarta: KencanaPrenada Media Group

Suharto, Edi, (2005), Public Policy Analysis, Bandung: Alphabet

Suharto, Edi, (2008), Social Policy as Public Policy, Bandung: Alfabeta

Suharto, Edi, (2009), Poverty and Social Protection in Indonesia, Bandung: Alfabeta

Taufiqurakhman, (2014), Public Policy, First Printing, Jakarta: Moestopo University Religious Press

\section{Website/internet}

https://www.google.com/amp/s/aceh.tribunnews.com/amp/2019/07/30/pengemis-di-Lhokseumawebanyak-warga-luar retrieved 10 September 2020

https://www.google.com/amp/s/aceh.tribunnews.com/amp/2019/09/19/miris-tak-bawa-uang-usaimengemis-bocahs-Lhokseumawe-ini-diduga-dipukul-hingga-dirantai-orangtuanya $\quad$ retrieved 10 September 2020

https://stoppneumonia.id/informasi-tentang-virus-corona-novel-coronavirus/ retrieved 25 September 2020 https://aceh.antaranews.com/berita/159810/positif-covid-19di-Lhokseumawe-meningkat-gtpp-terusmaksimalkan-upaya-penanganan retrieved 25 September 2020

https://aceh.tribunnews.com/2020/09/15/tak-pakai-masker-di-Lhokseumawe-dikenakan-sanksimembersihkan-rumput-di-taman-dan-hafal-ayat-quran retrieved 15 September 2020

https://aceh.tribunnews.com/2020/09/15/pemerintah-aceh-tak-punya-roadmap-penanganan-covidparahnya-lagi-merasa-pintar-sendiri retrieved 15 September 2020 